\title{
THE DISTRIBUTION OF METHIONINE- ENKEPHALIN AND LEUCINE-ENKEPHALIN IN THE BRAIN AND PERIPHERAL TISSUES
}

\author{
J. HUGHES, H.W. KOSTERLITZ \& T.W. SMITH' \\ Unit for Research on Addictive Drugs, University of Aberdeen, Marischal College, Aberdeen AB9 1AS
}

1 A method is described for the rapid extraction of opioid peptides from the brain and other tissues. The method is based on acid extraction of tissues followed by adsorption of the extract onto Amberlite XAD-2 resin. Elution with methanol separates the enkephalins and $\alpha$-endorphin from $\beta$-endorphin.

2 Over $90 \%$ of the opioid peptide activity isolated from brain and gut of several species by our method was due to methionine- and leucine-enkephalin. In contrast, the major opioid peptide activity recovered from the pituitary was due to peptides of much greater mol. wt. than the enkephalins.

3 An opioid peptide with properties unlike those of the known endorphins or enkephalins was present in brain extracts. This peptide, termed $\epsilon$-endorphin, has an apparent mol. wt. of 700 to 1200; it constituted between 5 to $10 \%$ of the total opioid activity in our extracts.

4 A differential assay of methionine- and leucine-enkephalin was made either by destroying methionine-enkephalin activity with cyanogen bromide or by separating the peptides by thin layer chromatography.

5 The ratio of methionine-enkephalin to leucine-enkephalin varied greatly in different brain regions. The highest proportions of leucine-enkephalin were found in the cerebral cortex and hippocampus.

6 Formaldehyde perfusion and fixation of the brain in vivo had no significant effect on the brain content of enkephalin, indicating that proteolytic breakdown is not a major problem in the extraction of these peptides.

7 It is suggested that the enkephalins may have a neurotransmitter role in both brain and peripheral tissues and that methionine- and leucine-enkephalin may subserve separate neuronal functions.

\section{Introduction}

Two pentapeptides, methionine-enkephalin (Tyr-GlyGly-Phe-Met) and leucine-enkephalin (Tyr-Gly-GlyPhe-Leu) have been isolated from pig and cow brain (Hughes, Smith, Kosterlitz, Fothergill, Morgan \& Morris, 1975; Simantov \& Snyder, 1976a). These peptides are of considerable interest since they act as agonists at opiate receptor sites; it has been proposed that they may function as neurotransmitter agents at morphine-sensitive synapses (Hughes, 1975; Kosterlitz \& Hughes, 1975).

The original isolation of the enkephalins (Hughes, Smith, Morgan \& Fothergill, 1975) involved somewhat lengthy extraction and chromatographic procedures. It was therefore possible that the enkephalins may have been artefacts arising from the breakdown of larger peptides prior or subsequent to

\footnotetext{
1 Present address: Pharmacology Department, Wellcome Research Laboratories, Langley Court, Beckenham, Kent.
}

extraction, although no evidence for this was ever obtained. We have now developed rapid and simple methods for the isolation and assay of the enkephalins. These methods have been used to determine the distribution of the peptides and to establish that they are indeed normal constituents of body tissues.

A preliminary report of this work was given at a meeting of the International Narcotic Research Conference (Smith, Hughes, Kosterlitz \& Sosa, 1976).

\section{Methods}

\section{Tissue extraction}

Unless otherwise specified, animals were killed by cervical dislocation and exsanguination. The brain was removed as rapidly as possible and individual brain areas dissected out on an ice-cooled plate. 
Segments of the gastro-intestinal tract were removed and the lumenal contents were washed out with cold $0.9 \% \mathrm{w} / \mathrm{v} \mathrm{NaCl}$ solution (saline). The longitudinal muscle-myenteric plexus layer was separated from the circular muscle-mucosal layer as described by Paton $\& \mathrm{Zar}$ (1968). Tissues were minced with scissors and homogenized (Ultra-Turrax homogenizer) in ice cold $0.1 \mathrm{M} \mathrm{HCl}(5 \mathrm{ml} / \mathrm{g}$ tissue). The homogenate was centrifuged at $4^{\circ} \mathrm{C}$ for $15 \mathrm{~min}$ at $10,000 \mathrm{~g}$ and the supernatant was retained. Glassware used in this and all other subsequent procedures was siliconized before use.

A crude subcellular fractionation was made by homogenizing whole brain with ten volumes of ice cold $0.32 \mathrm{M}$ sucrose (adjusted to $\mathrm{pH} 7.3$ with $\mathrm{NaOH}$ ) in a Potter-Elveheim homogenizer (10 strokes at $2000 \mathrm{rev} /$ minute). The homogenate was centrifuged at $1000 \mathrm{~g}$ for $10 \mathrm{~min}$ to give a nuclear pellet $\left(\mathrm{P}_{1}\right)$; centrifugation of the first supernatant and nuclear pellet washings at $17,000 \mathrm{~g}$ for $20 \mathrm{~min}$ gave a $\mathrm{P}_{2}$ pellet.

\section{Chromatography}

Amberlite XAD-2 (BDH) is a neutral polystyrene bead resin capable of adsorbing many hydrophobic compounds. It was purified by successive extractions with dichloromethane $(5 \mathrm{ml} / \mathrm{g})$, propan-1-ol $(10 \mathrm{ml} / \mathrm{g}$, twice) and methanol (10 ml $/ \mathrm{g}$, three times). The resin was finally washed with distilled water until it was free of methanol. Samples were adsorbed onto an $8 \times 0.9 \mathrm{~cm}$ column of the resin at a flow rate of $1 \mathrm{ml} / \mathrm{minute}$. The column was then washed with $20-30 \mathrm{ml}$ of $1 \mathrm{M} \mathrm{HCl}$ and $50-80 \mathrm{ml}$ distilled water $(5-6 \mathrm{ml} / \mathrm{min})$ and the enkephalins eluted with $40 \mathrm{ml}$ $90 \%$ methanol. This eluate was taken to dryness under reduced pressure at $40^{\circ} \mathrm{C}$; when required for bioassay the samples were dissolved in $0.15-0.3 \mathrm{ml}$ of Krebs solution.

Aminex-A28-formate (7-9 $\mu \mathrm{m}$ spherical anion exchange resin, Bio-Rad Laboratories) was slurrypacked into a $9 \times 1 \mathrm{~cm}$ glass column and equilibrated with $0.15 \mathrm{M}$ formate, $\mathrm{pH} 8.8$. Samples $(0.5 \mathrm{ml}$ at pH 8.8) were applied via an injection head. Elution with the initial buffer solution was continued for $20 \mathrm{~min}$ (flow rate $1 \mathrm{ml} / \mathrm{min}$ delivered by a Milton Roy minipump at $200 \mathrm{lb} / \mathrm{in}^{2}$ ) and then this was changed to $0.2 \mathrm{M}$ ammonium formate, $\mathrm{pH} 4.6$, for $30 \mathrm{~min}$ followed by a final change to $0.2 \mathrm{M}$ formic acid solution containing $30 \%(\mathrm{v} / \mathrm{v})$ methanol.

Sephadex G-15 gel permeation was carried out with slurry-packed columns $(100 \times 0.4 \mathrm{~cm})$ equilibrated with $3.5 \mathrm{M}$ acetic acid. Samples $(0.1-0.2 \mathrm{ml})$ were introduced via an injection head and the column was eluted with $3.5 \mathrm{M}$ acetic acid at a flow rate of $0.1 \mathrm{ml} /$ minute. The u.v. absorption of the effluent was monitored at $280 \mathrm{~nm}$ with a Laboratory Data Control continuous flow spectrometer.

Thin layer chromatography (t.l.c.) was carried out on $0.25 \mathrm{~mm}$ silica gel plates $(\mathrm{BDH})$ without any pre- conditioning. Samples, dissolved in $30-40 \mu \mathrm{l}$ of methanol containing $1 \mu \mathrm{g}$ ascorbic acid, were spotted in $3 \mu \mathrm{l}$ aliquots to a total volume of $15 \mu \mathrm{l}$ per spot. The plates were developed with a mixture of ethyl acetate:pyridine: water:acetic acid $(50: 22: 13: 6)$. Marker lanes were sprayed with ninhydrin in order to locate the peptides. Areas to be eluted were scraped free from the plate with a spatula and sucked into a $1 \mathrm{ml}$ plastic cone where the silica gel was retained by a cotton wool plug. The samples were eluted with $0.2 \mathrm{ml}$ of saline and directly assayed.

\section{Cyanogen bromide treatment}

Samples were dissolved in $0.2 \mathrm{ml}$ of $0.1 \mathrm{M} \mathrm{HCl}$ and $1 \mathrm{mg}$ of cyanogen bromide in $0.1 \mathrm{ml}$ of $0.1 \mathrm{M} \mathrm{HCl}$ added. The plastic tube which contained the mixture was sealed and incubated at $40^{\circ} \mathrm{C}$ with intermittent shaking for 90 minutes. The sample was then frozen and freeze-dried. The opiate agonist activity of 0.01 to $10 \mu \mathrm{g}$ of methionine-enkephalin was reduced by $91-94 \%$ by this procedure whilst that of leucineenkephalin was unchanged. Methionine-enkephalin and leucine-enkephalin could therefore be separately determined in a mixture by assaying samples before and after cyanogen bromide treatment.

\section{Enzyme studies}

Peptide fractions were dissolved in $0.1 \mathrm{ml}$ Krebs solution and $10 \mu \mathrm{g} / \mathrm{ml}$ of either carboxypeptidase-A or leucine-aminopeptidase (Sigma) added. The mixture was incubated for $30 \mathrm{~min}$ at $37^{\circ} \mathrm{C}$ with intermittent shaking. Controls were treated similarly except that the enzyme was boiled for $5 \mathrm{~min}$ before addition to the incubate. At the end of the incubation period the samples were placed on ice and immediately assayed for opiate-like activity.

\section{Bioassay}

Opioid peptide activity was measured by bracket assay on the mouse vas deferens electrically stimulated at $0.1 \mathrm{~Hz}$ with rectangular pulses of $0.3 \mathrm{~ms}$ (Hughes, Kosterlitz \& Leslie, 1975; Hughes, 1975). The majority of the bioassays were carried out with a $3 \mathrm{ml}$ assay bath; however, very small amounts of activity were assayed in a $0.7 \mathrm{ml}$ micro-bath. A minimum amount of $0.5 \mathrm{ng}$ of methionine-enkephalin could be assayed by use of the micro-bath. In the bioassay, leucine-enkephalin was $1.56 \pm 0.13$ times $(n=38)$ more active than methionine-enkephalin. The reversal by the opiate antagonist naloxone $(900 \mathrm{nM})$ was used to test for the specificity of the inhibition of the contractions. The 'total' enkephalin activity of tissue extracts was assayed against synthetic methionine-enkephalin whilst cyanogen bromidetreated samples or leucine-enkephalin spots from the t.l.c. were assayed against synthetic leucine- 
enkephalin. Extracts of 'large peptides' (endorphins) were assayed against $\beta$-endorphin $\left(\beta\right.$-lipotropin $\left.{ }_{61-91}\right)$ or $\alpha$-endorphin $(\beta$-lipotropin $61-76)$.

\section{Solutions and materials}

Aminex-A28 high pressure anion exchange beads were purchased from Bio-Rad Ltd and cyanogen bromide from Eastman Chemicals.

Ninhydrin spray was prepared by freshly mixing 6 volumes of ninhydrin in acetone $(10 \mathrm{mg} / \mathrm{ml})$ with one volume of cadmium acetate $(1 \mathrm{~g}$ in $50 \mathrm{ml}$ acetic acid $+150 \mathrm{ml}$ water).

The Krebs solution for bioassay had the following composition (mM): $\mathrm{NaCl} 118, \mathrm{KCl} 4.75, \mathrm{CaCl}_{2} 2.54$, $\mathrm{NaHCO}_{3} 24, \mathrm{KH}_{2} \mathrm{PO}_{4} 0.93$ and glucose 11 .

\section{Results}

\section{Isolation of synthetic peptides on XAD-2 columns}

Both enkephalins were completely retained on XAD-2 columns in aqueous solution over a $\mathrm{pH}$ range of $1.5-8.0$ and a buffer molarity range of $0.1-1.0 \mathrm{M}$. A consistent recovery of $90-94 \%$ of both peptides was obtained when the columns were eluted with $50 \mathrm{ml}$ of $90 \%(\mathrm{v} / \mathrm{v})$ methanol. Equally good recoveries were obtained with mixtures of equal volumes of methanol and water or of propan-1-ol and water. Retention and elution of the peptides was the same for a range of column loading of 0.01 to $100 \mu \mathrm{g}$ of enkephalin.

Fragments $61-68,61-69$ and $61-76$ of $\beta$ lipotropin were completely retained on XAD-2 and were eluted in $50 \%$ methanol-water with yields of $35 \pm 6 \%, 65 \pm 7 \%$ and $50 \pm 4 \%$, respectively $(n=3)$. $\beta$ Lipotropin $_{61-91}(\beta$-endorphin) was also completely retained but could not be eluted even with mixtures of methanol-pyridine-water or chloroform-pyridinewater.

\section{Composition of XAD-2-treated extracts}

Brain and guinea-pig ileum. Reconstituted XAD-2 eluates from brain and gut produced dose-related, naloxone-reversible inhibitions of the electrically stimulated mouse vas deferens. The inhibition was quick in onset and offset of action as described previously (Hughes, 1975). Washing the columns with $1 \mathrm{M} \mathrm{HCl}$ after adsorption of the peptides was particularly important with some extracts (e.g. cerebral cortex) as it removed inhibitory activity not reversible by naloxone from the extract. Recovery of enkephalins from the tissues was estimated by addition of $500 \mathrm{ng}$ of methionine- or leucineenkephalin to the $0.1 \mathrm{M} \mathrm{HCl}$ used for homogenization of one half of a rat brain. Recovery of added enkephalin was $86 \pm 6 \%(n=4)$ when the sample was corrected for the endogenous content determined in

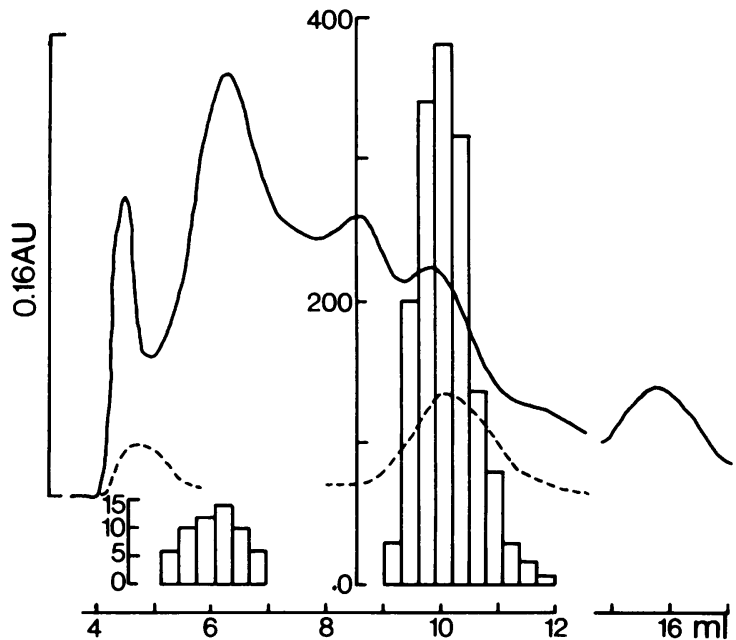

Figure 1 Sephadex G-15 chromatography of Amberlite XAD-2 eluate from the extract of two rabbit brains. The whole brain minus the cerebellum was homogenized in $0.1 \mathrm{M} \mathrm{HCl}$ and adsorbed onto XAD-2 resin as described in the Methods section. Solid trace: u.v. absorption at $280 \mathrm{~nm}$ of column effluent $(10 \mu$ flow cell, $1 \mathrm{~cm}$ light path, $0.16 \mathrm{AU}$ full scale). Broken trace: u.v. absorption at $280 \mathrm{~nm}$ of authentic marker $\alpha$-endorphin $(10 \mu \mathrm{g})$ and methionine-enkephalin $(20 \mu \mathrm{g})$. Histograms: opioid activity detected by bioassay of column effluent and expressed as $\mathrm{ng}$ of methionine-enkephalin. Abscissa scale: column effluent volume recorded from start of experiment.

the other half-brain to which no enkephalin had been added. Addition of $1-5 \mu \mathrm{g}$ of $\beta$-endorphin to the $0.1 \mathrm{M}$ $\mathrm{HCl}$ used for homogenization did not result in additional enkephalin activity in the final extract $(n=3)$.

The composition of XAD-2-treated extracts of brain and whole guinea-pig ileum was examined by Sephadex G-15 and t.l.c. The effluent from the Sephadex column showed a number of substances that absorbed u.v. at $280 \mathrm{~nm}$ (Figure 1). However, in both brain and guinea-pig ileum extracts over $95 \%$ of the opiate-like activity eluted at the same position as the enkephalins. One other minor peak of opiate-like activity eluted in the mol. wt. range of 800-1200 daltons; its elution volume did not correspond with the elution volumes of either $\beta$-lipotropin l1-76 $(\alpha$ endorphin) or $\beta$-lipotropin ${ }_{61-68}$. The unknown compound(s) was termed $\varepsilon$-endorphin.

Complete resolution of methionine- and leucineenkephalin was seen on thin layer chromatography with $R_{\mathrm{F}}$ values of 0.32 and 0.42 for the respective peptides. In this system $\beta$-lipotropin fragments $61-68$, $61-69,61-76$ and $61-91$ remained at the origin. T.l.c. of the XAD-2-treated extracts of rabbit, rat, mouse and 
guinea-pig brain followed by bioassay revealed two major bands having opiate-like activity corresponding to methionine- and leucine-enkephalin. No activity was detected at the origin but a minor band of opiate-like activity was found with an $R_{\mathrm{F}}$ value of 0.18 .

It should be noted that none of the methods described above yield pure preparations of peptides. Contamination with other u.v. absorbing materials is apparent when these samples are subjected to high pressure chromatography (Hughes, Kosterlitz, McKnight \& Sosa, unpublished observations). Therefore the enkephalins cannot be estimated by u.v. absorbance determinations with these methods. However, the samples are 'biologically pure', that is the enkephalins and endorphins are completely separated and the activity on the mouse vas deferens is completely reversed by naloxone.

Pituitary gland. XAD-2-treated extracts of rabbit pituitary also produced dose-related inhibitions of the mouse vas deferens. However, the effect was slow in onset and offset and naloxone only caused a $50-60 \%$ reversal of the inhibition. Sephadex G-15 gel chromatography of these extracts showed that the major portion (95\%) of naloxone-reversible activity eluted in the mol. wt. range of 1200-1500 daltons. The remainder of the opiate-like activity eluted in the same effluent volume as the enkephalins. In our t.l.c. system most of the pituitary activity remained at the origin but a small amount of activity (2-3\%) migrated to the same position as leucine-enkephalin.

For comparison, samples of rabbit pituitary and striatum and of guinea-pig myenteric plexus were homogenized in $0.1 \mathrm{M} \mathrm{HCl}$, but instead of extraction with XAD-2 resin which eliminates very large peptides, the samples were lyophylized and applied to a Sephadex G-15 column and the effluent bioassayed. Considerable amounts of large endorphin activity (effluent volume $3-5.5 \mathrm{ml}$ ) were found in pituitary extracts (Table 1) together with very small amounts of enkephalin activity (effluent volume 9-12 ml). Striatal extracts contained large amounts of 'enkephalin-like' peptides and smaller amounts of the larger peptides (Table 1); these findings were confirmed by t.l.c. The larger peptides could not be detected in extracts of myenteric plexus where the minimum detection limit was calculated to be $0.1 \mathrm{nmol} / \mathrm{g}$; however, the concentration of enkephalin in the myenteric plexus was equivalent to that found in the striatum.

\section{Identity of $\varepsilon$-endorphin}

Apart from the enkephalins, the only other peak of opiate-like activity found in Sephadex G-15 eluates of $\mathrm{XAD}$-2-treated extracts of brain was a compound we have termed $\varepsilon$-endorphin. This activity was completely destroyed on incubation with carboxypeptidase and leucine-aminopeptidase and was therefore peptide-like in nature. It could also be detected by t.l.c. $\left(R_{\mathrm{F}}=0.18\right)$ of XAD-2 extracts of brain or on elution of brain extracts from Aminex-A28. $\varepsilon$-Endorphin emerged from an A-28 column during formic acid elution at $\mathrm{pH} 3.7-3.4$, before the enkephalins which eluted at pH 3.1-2.7.

In five experiments on rabbit brain, $10 \pm 2.4 \%$ of total activity from the A-28 eluates was due to $\varepsilon$ endorphin. When $\varepsilon$-endorphin was isolated by adsorption on XAD-2 and then separated from enkephalins by t.l.c., it was found that it constituted $4.5 \pm 2 \%(n=4)$ of the total recoverable opiate-like activity. High voltage electrophoresis $(\mathrm{pH} 2,2 \mathrm{kV}$ for $1 \mathrm{~h}$ ) of $\varepsilon$-enkephalin gave a mobility relative to valine of +0.56 which was slower than that of the enkephalins which had a mobility of +0.61 . Estimates of mol. wt. from Sephadex G-15 chromatography and electrophoresis both indicate a peptide somewhat larger than enkephalin in the range of 700 to 1200 daltons.

Treatment with cyanogen bromide destroyed $61 \pm 4 \%(n=3)$ of the biological activity of $\varepsilon$ -

Table 1 Enkephalin and endorphin concentrations in different tissues

\begin{tabular}{|c|c|c|c|c|}
\hline \multirow[b]{3}{*}{$\begin{array}{l}\text { Rabbit pituitary } \\
\text { Rabbit striatum } \\
\text { Guinea-pig myenteric }\end{array}$} & \multicolumn{2}{|c|}{ G-15 chromatography } & \multicolumn{2}{|c|}{$\begin{array}{l}X A D-2 \text { and } G-15 \\
\text { chromatography }\end{array}$} \\
\hline & Endorphins & g) Enkephalins & Endorphins $†$ & Enkephalins \\
\hline & $\begin{array}{c}34 \pm 3 \\
0.43 \pm 0.1 \\
\text { not } \\
\text { detectable }\end{array}$ & $\begin{array}{l}0.02 \pm 0.005 \\
0.82 \pm 0.08 \\
0.85 \pm 0.1\end{array}$ & $\begin{array}{c}1.1 \pm 0.15 \\
0.02 \ddagger \\
\text { not } \\
\text { detectable }\end{array}$ & $\begin{array}{c}0.01 \ddagger \\
0.76 \pm 0.1 \\
0.80 \pm 0.13\end{array}$ \\
\hline
\end{tabular}

Tissues were extracted with $\mathrm{HCl}$ as in Methods and assayed for opioid activity after adsorption and elution from Amberlite XAD-2 and chromatography on Sephadex G-15 or after Sephadex G-15 separation without prior absorption on XAD-2. The endorphins (mol. wt. $>1000$ ) eluted from G-15 between $3-5.5 \mathrm{ml}$ and the enkephalins between 9-12 ml. Endorphins were assayed against $\beta$-endorphin (") or $\alpha$-endorphin ( $t$ ). Results are the means \pm s.e. of 4 experiments except $(\ddagger)$ where the mean of two experiments is given, there being no detectable activity in two other experiments. 
endorphin which in comparison with the $92 \%$ destruction of methionine-enkephalin may indicate a mixture of peptides. An amino acid analysis was unsuccessful due to the small amounts of material available.

\section{Distribution of enkephalins}

The following results were obtained from the bioassay of XAD-2 eluates. The whole brain (minus cerebellum) levels of the enkephalins were very similar in the mouse, rat, guinea-pig and rabbit (Table 2). In each species there was 3 to 3.5 times more methionineenkephalin than leucine-enkephalin as determined by either the cyanogen bromide technique or thin layer chromatography (Table 2). Individual brain areas from the rabbit and guinea-pig were analysed (Tables 3 and 4). The highest concentrations of both peptides

Table 2 Enkephalin content of whole brain

\begin{tabular}{lrcccc} 
& \multicolumn{9}{c}{ Cyanogen bromide assay } & t.l.c. assay \\
& $n$ & $M E$ & $L E$ & Ratio & Ratio \\
Mouse & \multicolumn{1}{c}{ (pmol/g) } & & & \\
Rat & 9 & $139 \pm 9$ & $39 \pm 4$ & 3.6 & $3.2 \pm 0.1$ \\
Guinea-pig & 10 & $170 \pm 11$ & $46 \pm 3$ & 3.7 & $3.4 \pm 0.4$ \\
Rabbit & 4 & $160 \pm 9$ & $45 \pm 6$ & 3.6 & $3.7 \pm 0.4$ \\
& 6 & $154 \pm 12$ & $51 \pm 7$ & 3.0 & $2.8 \pm 0.3$
\end{tabular}

$M E=$ methionine-enkephalin; $L E=$ leucine-enkephalin. The peptides were differentially assayed by determining opioid activity before and after treatment with cyanogen bromide. The ratios of the two peptides were also determined after separation by t.l.c. $n=$ number of experiments.

Table 3 Distribution of enkephalins in guinea-pig brain

\begin{tabular}{|c|c|c|c|c|}
\hline & \multicolumn{3}{|c|}{ Cyanogen bromide assay } & \multirow{2}{*}{$\begin{array}{c}\text { t.l.c. assay } \\
\text { Ratio }\end{array}$} \\
\hline & $M E$ & $L E$ & Ratio & \\
\hline $\begin{array}{l}\text { Cortex } \\
\text { Hippocampus } \\
\text { Striatum } \\
\text { Pons + medulla } \\
\text { Thalamus } \\
\text { Hypothalumus } \\
\text { Cerebellum }\end{array}$ & $\begin{array}{r}67 \pm 9 \\
150 \pm 11 \\
750 \pm 41 \\
139 \pm 12 \\
157 \pm 12 \\
453 \pm 52 \\
<10\end{array}$ & $\begin{array}{c}51 \pm 5 \\
70 \pm 9 \\
180 \pm 25 \\
20 \pm 5 \\
21 \pm 3 \\
54 \pm 18 \\
<10\end{array}$ & $\begin{array}{l}1.3 \\
2.1 \\
4.2 \\
6.9 \\
7.4 \\
8.4\end{array}$ & $\begin{array}{l}1.5 \\
1.7 \\
4.0 \\
5.8 \\
6.3 \\
-\end{array}$ \\
\hline
\end{tabular}

$M E=$ methionine-enkephalin; $L E=$ leucine-enkephalin. The peptides were differentially assayed by determining opioid activity before and after treatment with cyanogen bromide. The means \pm s.e. of 4 experiments are shown. In two separate experiments the ratio of the two peptides was determined after separation by t.l.c.

Table 4 Distribution of enkephalins in rabbit brain

\begin{tabular}{|c|c|c|c|c|}
\hline & \multicolumn{3}{|c|}{ Cyanogen bromide assay } & \multirow{2}{*}{$\begin{array}{c}\text { t.I.c. assay } \\
\text { Ratio }\end{array}$} \\
\hline & $M E$ & $L E$ & Ratio & \\
\hline $\begin{array}{l}\text { Cortex } \\
\text { Hippocampus } \\
\text { Striatum } \\
\text { Pons + medulla } \\
\text { Thalamus } \\
\text { Hypothalamus } \\
\text { Cerebellum }\end{array}$ & $\begin{array}{r}42 \pm 7 \\
85 \pm 11 \\
681 \pm 31 \\
145 \pm 11 \\
162 \pm 14 \\
575 \pm 63 \\
52 \pm 4\end{array}$ & $\begin{array}{r}29 \pm 7 \\
49 \pm 18 \\
209 \pm 38 \\
50 \pm 7 \\
38 \pm 8 \\
100 \pm 13 \\
<10\end{array}$ & $\begin{array}{l}1.5 \\
1.7 \\
3.0 \\
2.9 \\
4.3 \\
5.8 \\
\infty\end{array}$ & $\begin{array}{l}1.6 \\
2.2 \\
3.7 \\
3.5 \\
3.8 \\
4.8 \\
\infty\end{array}$ \\
\hline
\end{tabular}

$M E=$ methionine-enkephalin; $L E=$ leucine-enkephalin. Means \pm s.e. of 4 experiments where the peptides were differentially assayed by the cyanogen bromide technique. The ratios as determined after t.l.c. represent the means of 2 experiments. 
were found in the striatum and hypothalamus. However, there were marked variations in the ratio of the two peptides in different brain areas; in the guineapig there were about equal amounts in the cerebral cortex but in the hypothalamus there was up to eight times more methionine-enkephalin than leucineenkephalin. In the rabbit the variation was not as large as in the guinea-pig but the pattern was similar. The main difference between the species was the presence of appreciable quantities of methionine-enkephalin in the rabbit cerebellum, but very little leucineenkephalin, whilst no appreciable opiate-like activity could be detected in the guinea-pig cerebellum.

Appreciable quantities of the enkephalins were detected in the small intestine of the guinea-pig, rabbit, mouse and rat (Table 5) with the largest amounts

Table 5 Enkephalin content of gastro-intestinal tract

\begin{tabular}{|c|c|c|}
\hline \multicolumn{3}{|c|}{$\begin{array}{c}\text { Total enkephalin } \\
(\mathrm{pmol} / \mathrm{g})\end{array}$} \\
\hline $\begin{array}{l}\text { Mouse ileum } \\
\text { Rat ileum* } \\
\text { Rabbit ileum }\end{array}$ & $\begin{array}{l}4 \\
5 \\
4\end{array}$ & $\begin{array}{r}18 \pm 2 \\
25 \pm 6 \\
120 \pm 13\end{array}$ \\
\hline $\begin{array}{l}\text { Guinea-pig } \\
\text { stomach } \\
\text { duodenum } \\
\text { ileum } \\
\text { caecum } \\
\text { colon }\end{array}$ & $\begin{array}{l}3 \\
3 \\
3 \\
3 \\
3\end{array}$ & $\begin{array}{r}75 \pm 6 \\
390 \pm 14 \\
190 \pm 14 \\
60 \pm 10 \\
85 \pm 9\end{array}$ \\
\hline $\begin{array}{l}\text { Total enker } \\
\text { methionine-en } \\
\text { experiments. } \\
\text { a considerabl } \\
\text { was not reve } \\
\text { impossible t } \\
\text { accurately. }\end{array}$ & & $\begin{array}{l}\text { ayed against } \\
\text { Means } \pm \text { s.e. of } n \\
\text { ot recorded here } \\
\text { hibitory activity } \\
\text { it was therefore } \\
\text { ephalin activity }\end{array}$ \\
\hline
\end{tabular}

occurring in the first two species. The concentrations of the two peptides were determined in both the longitudinal muscle-myenteric plexus layer and in the circular muscle-mucosal layer of the ileum. The highest concentrations of both peptides was found in the myenteric plexus layer (Table 6), these concentrations being comparable to the concentration found in mid-brain areas. Both rabbit and guinea-pig whole ileum contained twice as much methionine-enkephalin as leucine-enkephalin although this ratio varied in the dissected gut layers (Table 6). Enkephalin activity was present throughout the gastro-intestinal tract of the guinea-pig (Table 5) with the highest concentrations occurring in the duodenum.

Other peripheral tissues also contained enkephalinlike activity, in particular the guinea-pig kidney, the cervical vagus and the atria from the rabbit and rat and the lumbar sympathetic chain and coeliac ganglion from the rabbit (Table 7). A positive indentification of the enkephalin activity could not be made in these peripheral tissues because of the very small quantities extracted. There was also a considerable variation in the amounts detected possibly because the assay was at the limits of its sensitivity. No activity could be detected in $50 \mathrm{ml}$ rabbit blood or vasa deferentia (500 to $700 \mathrm{mg}$ wet wt.) from rabbit, guinea-pig or mouse.

\section{Stability of enkephalins in brain}

Formaldehyde fixation was used to test if there was any change in total enkephalin levels between death and extraction of rat brain. Rats were anaesthetized with pentobarbitone and perfused through the carotid arteries with ice-cold $10 \%$ formaldehyde. On dissection, the brains of these animals were hard, bloodless and permeated with formaldehyde. No significant difference in total enkephalin levels was found between brains taken after cervical dislocation, pentobarbitone anaesthesia + exsanguination or after

Table 6 Enkephalin distribution in guinea-pig and rabbit ileum

\begin{tabular}{|c|c|c|c|c|}
\hline \multirow[b]{3}{*}{$\begin{array}{l}\text { Guinea-pig myenteric plexus } \\
\text { Rabbit myenteric plexus }\end{array}$} & \multicolumn{3}{|c|}{ Cyanogen bromide assay } & \multirow{2}{*}{$\begin{array}{l}\text { t.l.c. } \\
\text { ratio }\end{array}$} \\
\hline & \multicolumn{2}{|c|}{$(p m o l / g)$} & Ratio & \\
\hline & $\begin{array}{l}410 \pm 50 \\
270 \pm 36\end{array}$ & $\begin{array}{l}151 \pm 16 \\
113 \pm 14\end{array}$ & $\begin{array}{l}2.7 \\
2.4\end{array}$ & $\begin{array}{l}3.8 \\
2.2\end{array}$ \\
\hline $\begin{array}{l}\text { Guinea-pig circular muscle } \\
\text { Rabbit circular muscle }\end{array}$ & $\begin{array}{l}49 \pm 4 \\
25 \pm 2\end{array}$ & $\begin{array}{l}11 \pm 1 \\
21 \pm 6\end{array}$ & $\begin{array}{l}4.7 \\
1.5\end{array}$ & $\begin{array}{l}4.2 \\
0.9\end{array}$ \\
\hline
\end{tabular}

Methionine-(ME) and leucine-enkephalin (LE) concentrations were determined by assaying opiod activity before and after cyanogen bromide treatment. The means \pm s.e. of 4 experiments are shown. The ratio of methionine-enkephalin to leucine-enkephalin was also determined after t.l.c., the means of two separate experiments are shown. 
pentobarbitone anaesthesia + formaldehyde (Table 8). In a further group of rats the brains were left in situ for $1 \mathrm{~h}$ before dissection and extraction; there was a significant loss of enkephalin activity in the brains of these animals (Table 8).

As previously reported (Pasternak, Goodman \& Snyder, 1975; Smith et al., 1976), enkephalin activity was concentrated in the $P_{2}$ fraction of rat brain. The enkephalin levels of the $P_{2}$ fraction were measured at varying intervals after resuspension in Krebs solution at $36^{\circ} \mathrm{C}$. The enkephalin levels declined very slowly over a $90 \mathrm{~min}$ period, falling to $87 \%$ of initial values after $30 \mathrm{~min}(\mathrm{sc}=4 \%, n=4), 78 \pm 6 \%$ after $60 \mathrm{~min}$ and $69 \pm 6 \%$ after 90 minutes.

\section{Discussion}

The present results support the contention that the enkephalins are endogenous constitutents of brain and gut and possibly of other peripheral tissues. Extraction with $0.1 \mathrm{M} \mathrm{HCl}$ and adsorption on XAD-2 resin provides a rapid and simple procedure for isolating the enkephalins. Our analysis also shows that breakdown of larger endorphins to the enkephalins does not occur during this procedure. It is more difficult to exclude post-mortem changes as a source of enkephalins although the results described in this paper make this unlikely. The fixation of tissues with formaldehyde causes a small, though not significant, increase in

Table 7 Enkephalin-like activity in peripheral tissues

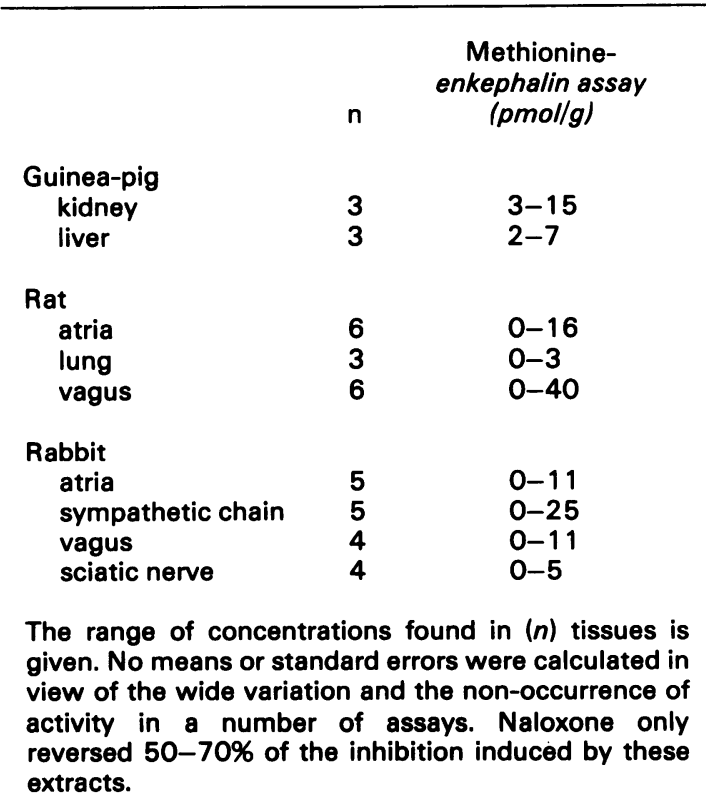

enkephalin levels. Thus, if proteolysis occurs during dissection without formaldehyde, it is possible that this leads to the loss and not the generation of enkephalins. In support of this view it is found that there is a significant fall in enkephalin levels when brains are extracted $1 \mathrm{~h}$ after death. However, when the $P_{2}$ fraction of brain homogenate was suspended in oxygenated, warmed Krebs solution then the enekephalin content was well maintained indicating a stable sequestration of the peptides.

Guillemin, Ling \& Burgus (1976) isolated and identified the opioid peptide $\alpha$-endorphin in pituitary extracts. A peptide of similar molecular weight is apparent in XAD-2-treated extracts of rabbit pituitary but no corresponding peptide could be detected in brain extracts. Thus it may be that $\alpha$-endorphin has its physiological function mainly in the pituitary, perhaps of a hormonal nature. Although only the enkephalins and $\varepsilon$-endorphin are detectable in XAD-2-treated $\mathrm{HCl}$ extracts of brain, it is clear from our results that larger endorphins are present in $\mathrm{HCl}$ extracts as shown by G-15 chromatography without prior adsorption onto XAD-2 resin. These results can only be regarded as semi-quantitative in the absence of chemical analysis and authentic standards; however, our results do allow certain comparisons to be made. In agreement with other authors (Cox, Opheim, Teschemacher \& Goldstein, 1975; Gentleman, Ross, Lowney, Cox \& Goldstein, 1976; Li \& Chung, 1976; Chrétien, Benjannet, Dragon, Seidah \& Lis, 1976) we found

Table 8 Enkephalin content of rat brain under different conditions

\begin{tabular}{|c|c|c|}
\hline & Conditions & $\begin{array}{c}\text { Enkephalin } \\
\text { content } \\
\text { (pmol/g) }\end{array}$ \\
\hline $\begin{array}{l}\text { (A) } \\
\text { (B) } \\
\text { (C) } \\
\text { (D) }\end{array}$ & $\begin{array}{l}3 \text { min after exsanguination } \\
1 \mathrm{~h} \text { after exsanguination } \\
\text { Pentobarbitone ( } 60 \mathrm{mg} / \mathrm{kg}) \\
\text { Pentobarbitone }+ \\
\text { formaldehyde }\end{array}$ & $\begin{array}{c}189 \pm 19 \\
82 \pm 11^{*} \\
207 \pm 16 \\
235 \pm 23\end{array}$ \\
\hline \multicolumn{3}{|c|}{$\begin{array}{l}\text { Total enkephalin activity is expressed as methionine- } \\
\text { enkephalin, results are the mean } \pm \text { s.e. of } 4 \\
\text { experiments. In groups } A \text { and } B \text { the rats were stunned } \\
\text { and the head cut off; the brains were dissected out } \\
\text { and the cerebellum removed } 3 \text { min and } 60 \text { min, } \\
\text { respectively, after death. Groups } C \text { and } D \text { were } \\
\text { anaesthetized with pentobarbitone }(60 \mathrm{mg} / \mathrm{kg}) \text {, after } \\
30 \text { min the head was removed and the brain } \\
\text { extracted (C) or } 10 \mathrm{ml} \text { of } 10 \% \text { formaldehyde in saline } \\
\text { was perfused via a } 20 \mathrm{ml} \text { syringe through one carotid } \\
\text { artery and then the brain was removed (D). } \\
\text { " Significantly different from } A, C \text {, and } D(P<0.01) \text {. }\end{array}$} \\
\hline
\end{tabular}


very large amounts of high molecular weight $(\geqslant 1500)$ opioid peptides in the pituitary. These endorphins are also present in much smaller amounts in the striatum but are not detectable in myenteric plexus extracts. In contrast, there are minute amounts of enkephalin in the pituitary but appreciable quantities in the striatum and myenteric plexus. From these results it seems unlikely that the enkephalins could be formed from endorphins during extraction since there is no obvious reason why this should occur in brain tissue but not pituitary tissue.

The presence of methionine- and leucine-enkephalin in the brains of several species has now been confirmed by two independent methods. Although similar ratios of the methionine- and leucine-peptides are seen in whole brain extracts it is apparent that the ratio varies considerably in different brain regions. This variation has also been noted by radioimmunoassay in different regions of the rat brain (Simantov \& Snyder, 1976b). It seems likely therefore that methionine- and leucine-enkephalin may exist in two separate neurotransmitter systems with possibly diverse functions.

In common with a number of other brain peptides, the enkephalins are found in the intestine where their high concentration in the longitudinal musclemyenteric plexus layer indicates an association with neural elements. Preliminary immunohistochemical results also show the presence of 'enkephalinergic'

\section{References}

CAIRNIE, A.B., KOSTERLITZ, H.W. \& TAYLOR, D.W. (1961). Effect of morphine on some sympathetically innervated effectors. Br. J. Pharmac. Chemother., 17, 539-555.

CHRÉTIEN, M., BENJANNET, S., DRAGON, N., SEIDAH, N.G. \& LIS, M. (1976). Isolation of peptides with opiate activity from sheep and human pituitaries: Relationship to $\beta$-lipotropin. Biochem. biophys. Res. Comm., 72, 472-477.

COX, B.M., OPHEIM, K.E., TESCHEMACHER, H. \& GOLDSTEIN, A. (1975). A peptide-like substance from pituitary that acts like morphine. Life Sci., 16, 1777-1782.

ELDE, R., HÖKFELT, T., JOHANSSON, O. \& TERENIUS, L. (1976). Immuno-histochemical studies using antibodies to leucine-enkephalin: initial observations on the nervous system of the rat. Neuroscience, 1, 349-351.

GENTLEMAN, S., ROSS, M., LOWNEY, L.I., COX, B.M. \& GOLDSTEIN, A. (1976). Pituitary endorphins. In Opiates and Endogenous Opioid Peptides, ed. Kosterlitz, H.W. Amsterdam: Elsevier/North-Holland Press.

GUILlEMIN, R., LING, N. \& BURGUS, R. (1976). Endorphines, peptides d'origine hypothalamique et neurohypophysaire à activité morphinométique. Isolement et structure moléculaire d'a-endorphin. C.R. hebd. Séances Acad. Sci., Paris D, 274, 783-785.

HUGHES, J. (1975). Isolation of an endogenous compound from the brain with pharmacological properties similar to morphine. Brain Res., 88, 295-308. neurones in the intestine (Elde, Hökfelt, Johansson \& Terenius, 1976). Further there is direct evidence that enkephalinergic mechanisms may act to modulate acetylcholine release in the guinea-pig myenteric plexus (Waterfield \& Kosterlitz, 1975).

The significance of the small amounts of enkephalins found in other peripheral tissues is uncertain although the rat and rabbit atria (Cairnie, Kosterlitz \& Taylor, 1961; Kennedy \& West, 1967) and guinea-pig kidney (C.B. Pert, personal communcation) do possess opiate receptors. The wholly unexpected finding of enkephalin activity in sympathetic ganglia and the vagus nerve suggests that the enkephalins may have a widespread role in the control of peripheral autonomic activity.

In conclusion, the enkephalins although possibly derived from larger precursor peptides are normal constituents of central and peripheral tissues. The peptides appear to be associated with nervous elements where they appear to be retained in a stable form under physiological conditions.

This work was supported by grants to H.W.K. from the Medical Research Council and the U.S. National Institute on Drug Abuse (DA 00662). We are most grateful for gifts of pure synthetic $\alpha$-endorphin from $\operatorname{Dr} \mathrm{R}$. Guillemin, $\beta$ endorphin from $\operatorname{Dr}$ C.H. $\mathrm{Li}$, methionine- and leucineenkephalin from Dr B.A. Morgan (Reckitt and Colman Ltd) and of lipotropin fragments 61-68 and 61-69 from Dr D.G. Smyth (National Institute of Medical Research).

HUGHES, J., KOSTERLITZ, H.W. \& LESLIE, F.M. (1975) Effect of morphine on adrenergic transmission in the mouse vas deferens. Assessment of agonist and anatgonist potencies of narcotic analgesics. $\mathrm{Br} . \mathrm{J}$. Pharmac., 53, 371-381.

HUGHES, J., SMITH, T.W., KOSTERLITZ, H.W., FOTHERGILL, L.A., MORGAN, B.A. \& MORRIS, H.R. (1975). Identification of two related pentapeptides from the brain with potent opiate agonist activity. Nature, Lond., 258, 577-579.

HUGHES, J., SMITH, T.W., MORGAN, B.A. \& FOTHERGILL, L.A. (1975). Purification and properties of enkephalin - the possible endogenous ligand for the morphine receptor. Life Sci., 16, 1753-1758.

KENNEDY, B.L. \& WEST, T.C. (1967). Effect of morphine on electrically induced release of autonomic mediators in the rabbit sinoatrial node. J. Pharmac. exp. Ther., 157, 149-158.

KOSTERLITZ, H.W. \& HUGHES, J. (1975). Some thoughts on the significance of enkephalin, the endogenous ligand. Life Sci., 17, 91-96.

LI, C.H. \& CHUNG, D. (1976). Isolation and structure of an untriakontapeptide with opiate activity from camel pituitary glands. Proc. natn. Acad. Sci., U.S.A., 73, 1145-1148.

PASTERNAK, G.W., GOODMAN, R. \& SNYDER, S.H. (1975). An endogenous morphine-like factor in mammalian brain. Life Sci., 16, 1765-1769. 
PATON, W.D.M. \& ZAR, A.M. (1968). The origin of acetylcholine released from guinea-pig intestine and longi tudinal muscle strips. J. Physiol., Lond., 194, 13-33.

SIMANTOV, R. \& SNYDER, S.H. (1967a). Morphine-like peptides in mammalian brain: Isolation, structure elucidation, and interaction with the opiate receptor. Proc. natn. Acad. Sci. U.S.A., 73, 2515-2519.

SIMANTOV, R. \& SNYDER, S.H. (1976b). Brain pituitary opiate mechanisms: pituitary opiate receptor binding, radioimmunoassays for methionine enkephalin and leucine enkephalin. In Opiates and Endogenous Opioid Peptides, ed. Kosterlitz, H.W. Amsterdam: Elsevier/ North-Holland Press.
SMITH, T.W., HUGHES, J., KOSTERLITZ, H.W. \& SOSA, R.P. (1976). Enkephalins: isolation, distribution and function. In Opiates and Endogenous Opioid Peptides, ed. Kosterlitz, H.W. Amsterdam: Elsevier/North-Holland Press.

WATERFIELD, A.A. \& KOSTERLITZ, H.W. (1975). Setereospecific increase by narcotic antagonist of evoked acetylcholine output in guinea-pig ileum. Life Sci., 16, 1787-1792.

(Received April 27, 1977. Revised June 3, 1977.) 